ELK
Asia Pacific Journals
www.elkjournals.com

\title{
INFLUENCING FACTORS FOR CUSTOMER SATISFACTION OF MOBILE- MONEY SERVICES, WITH SPECIAL REFERENCE TO MCASH SERVICE BY MOBITEL, SRI LANKA
}

\author{
Chathura Thilakarathne \\ Cardiff Metropolitan University, United Kingdom/ \\ International College of Business and Technology, \\ Sri Lanka \\ Chathuratk.au@gmail.com
}

\author{
Nalin Abeysekera \\ International College of Business and Technology, \\ Sri Lanka \\ nalinabeysekera@gmail.com
}

\begin{abstract}
The highly competitive mobile telecommunication industry continuously urges the operators to introduce innovative services where mobile-money is considered as one of the cornerstone services within recent years. Despite the optimistic growth forecasts, mobile-money services have not reached the continued attraction of the subscribers. This empirical study was conducted with the main objective of identifying the key influencing factors for customer satisfaction of mobile-money services with special reference to mCash service by Mobitel, Sri Lanka. Detailed literature study was carried out to recognize influencing factors for customer satisfaction in the general context and specific to mobile money and related services. The established hypothesis was evaluated based on correlation analysis. Economical price perception and improved security showcased significant correlation whilst enhanced service convenience and quality of customer care showcased medium and null correlation respectively.
\end{abstract}

Keywords: Customer satisfaction, mobile-money, correlation, Cronbach's alpha, price perception, security.

\section{Introduction}

\subsection{Background - Mobitel Private Limited}

Sri Lanka Telecom, Mobitel is the second largest mobile operator in Sri Lanka claiming 23 percent mobile market share and 27 percent revenue share as at the completion of the year 2014 [36].

\subsubsection{Mobile-money Service}

Mobile Money services or mobile valet is a novel concept which offers the end subscriber to use the mobile portable devices as a standard savings bank account. In presence of a mobile valet service, the subscriber would be able to use the mobile 
device to fund transfers, payments and withdrawals. There are significant global references for mobile money services including M-PESA, the mobile money service of Safaricom-Kenya, today serving a 62 percent of the total population with 19.4 million active subscribers [33].

Dialog Telecom was the first operator to introduce mobile money services to Sri Lankan market in 2008. In 2012, Dialog relaunched their mobile payment service as eZcash by enabling the service offerings to cater to external payments, savings, fund transfer and withdrawals. Mobitel was not granted the approval to commence mobile money services until late 2013. Presently, Etisalat and Hutch, two other competitive mobile operators share Dialog eZcash platform and provide rebranded services to their subscribers.

\subsubsection{Mobitel mCash Services and Customer Satisfaction}

Despite mCash service was introduced as a breakthrough product, Mobitel has not been able to achieve expected subscriber and revenue targets of the mCash service. It is also identified that the year on year (YOY) growth of the service is declining. Based on these high-level observations it is evident that the customer satisfaction level of mCash service is not satisfactory and this research study aims to identify the key components of the customer satisfaction with respect to mobile money services.

\section{Review of Literature}

This chapter critically reviews the existing algorithms, theories and paradigms on customer satisfaction and its overall impact on customer adoption and retention, ultimately maintaining uninterrupted profit growth.

\subsection{Theoretical Study on Customer Satisfaction}

The traditional behavioural studies suggested that customer satisfaction is a more relative concept rather than an abstract paradigm, and generally evaluated based on a perceived standard on service quality [2], [30]. Along the timeline, researchers converged on the importance of measurement of customer satisfaction in a quantitative manner. The expectancy disconfirmation theory makes the first attempts in quantitative measurement of customer satisfaction [10], [32]. 
While addressing the short comings of traditional theories on customer satisfaction, expectancy disconfirmation paradigm was introduced in 1977 [28] and the research community regarded that it as the most comprehensive structural framework to analyse customer satisfaction [45]. Spreng, et al. [35] mention that satisfaction is composed of two attributes; infomation satisfaction and attribute satisfaction. One of the prominent critics on EDP is that the primary determinant of the comparative norm is the situational expectations which are unintentionally developed on the consumer by the intentional efforts of advertisers, manufacturers and other stakeholders. Westbrook et al.[43] claim that EDP does not consider the important factors creating the expectation norm, such as consumer's past experience and recommendations by third party referents in which the consumer believes in.

\subsection{Influencing Factors for Customer Satisfaction}

Oliver [29] defines that service quality is the equilibrium of people, processes and technology; and optimum management of above resources would lead to elevated service quality. Wirtz[44] identifies that the service quality is an important aspect of achieving customer satisfaction. Despite the scale of the business, it is widely seen that all levels of businesses consider loyalty programs are a successful tool in customer retention. These loyalty programs vary from direct price discounts to loyalty card schemes. O'Brien et al. [26] have highlighted five key parameters of a successful loyalty program; variety of rewards, ease of use, monetary value of rewards, probability of deeming rewards and intangible value of the rewards. O'Brien et al. [26] mention that the perceived value of the loyalty program is uniquely depend upon the individual and it is important to design loyalty programs in such a way that aspirations of each customer group is addressed. In an oligopolistic market conditions, service providers attempt to offer the best customer convenience and service flexibility to its subscribers in order to attract higher market share. Chang, et al. [8] define service convenience as the ability to reduce non-monetary costs for customers where time, effort and methodology are simplified. Churchill [9] mentions that, customer convenience is the key to attain sustained competitive 
advantage in homogeneous and oligopolistic markets. Shanker et al. [34] identify promotions and advertising as a methodology which could present services of intangible nature in a tangible manner. Promotions can develop situational experience and influence consumer on prepurchase decisions by making the consumer satisfied and comfortable in purchasing the product or service [14]. Kyriazopoulos et al. [23], [24] have conducted a detailed statistical and cluster analysis of the relationship between price perception and customer satisfaction of mobile phone users in Greece, where they could establish a clear link between price perception and customer satisfaction. Price perception is a major evaluating factor for the consumer in switching decision to competitor product. The customers often believed that they are been deceived by the service provider if the price perception is too high compared with a similar competitive product [15] and hence, customer should have a clear idea on for which attributes he is spending more. It is mentioned that while absolute price does not directly correlate with customer satisfaction; the price value or price perception can be directly linked with the same [22], [19]. Emerging payment systems such as electronic banking, online purchasing and mobile money services are gaining momentum over traditional payment mechanisms, however security of the payments is still an alarming factor. The same concept is stated by Bradley \& Stewart [5] regarding financial and banking sector. Security, risk and privacy of data are key influencing factors for a customer to switch into modern payment systems from legacy systems and if a service provider is capable of fulfilling security and risk factors of the customer, the service provider would have a loyal customer base [6]. While enhanced features offer a strong competitive advantage in a first mover scenario, advanced product features are almost a necessity when you are entering in to a price inelastic, monopolistic market [37].

\subsection{Key Influencing factors for Customer Satisfaction of Mobile- money services}

Mobile-money can be modelled as a service rather than a product. Unlike a product based business, service industry is hugely dependent on service quality or customer care. Hasebur [16] has done a comprehensive study on the correlation of 
customer satisfaction and service quality in a contact centre environment and the results provide that the presence of knowledgeable agents is the highest important factor for customer satisfaction. Similarly, quality of customer care service can be identified as a key influencing factor for this research study.

One of the major reasons for introducing novel services such as mobile money is to attract customers who specifically require service flexibility and convenience over traditional transaction methods. Hence, customer convenience is a key component of a successful mobile money service.

Kaura [21] highlights that service convenience is a key attribute in services retail shops, electronic banking and online shopping. Since, mobile money is positioned as an alternative for above functions, service convenience can be identified as a key attribute. Convenience has become a key decisive factor for time constrained customers [39].

Ali et al. [1] mention that the security and risk are the primal factors subscribers evaluate prior choosing modern money transaction service. With the mobile money service, a subscriber can even send money across geographical boarders and hence, it is very important to couple the mobile money account with national identity card at all times [7]. As per the TRCSL reports there is an increase of crimes conducted via mobile money services [20].

The Sri Lankan financial sector is heavily populated by banks and similar financial institutes whereas government banks cover over 70 percent of the market share. Over 50 percent of population carries a personal bank account [38]. Therefore, with an over 100 percent penetration of mobile phone users, mobile companies are in an advantageous position to penetrate in to untapped micro level market [13]. However, with the central bank regulations mobile operators cannot provide mobile money services at a lesser cost than banking institutes. Noorshella et al. [25] mention that a consumer usually compares prices with similar standard products when coming to a judgment of price fairness. Further, as per Ali, et al. [1], price should be justifiable based on the operating market segment and competitor offerings. Hence, as per the Kotler's view [27] the mobile money services should provide better product features and service experience in order to deliver a better price perception. 


\section{Significance of the research}

\subsection{Symptoms of the Problem}

Despite the high expectations and forecasts, Mobitel mCash service did not provide expected revolutionizing market growth. Even though, there were significant numbers of registered users, active user count was not steadily growing; in fact active user base was fluctuating and did not meet the expected transaction levels or revenue generation.

Fig. 1 describes the underperformance of mCash service which is also below the organic growth trend line.

(Refer Figure 1 Here)

\subsection{Defining the Research Problem}

As per the GSMA report [30], mobile money service was huge success in developing communities where the people are in need of a reliable, convenient micro financial solution. Case studies of Kenya, Philippines and other developing markets witness that similar developing socioeconomic communities adapt to mobile money services at higher rate. However, in Sri Lankan context where penetration of banks to households is below 50 percent, mobile money service did not take up as expected. Hence, this research is dedicated to analyse the low growth of mobile money services with reference to Mobitel mCash service.

\subsection{Limitations of the Study}

Since this research involves with comparing competitive mobile operator services, there are limitations in obtaining the actual information and forecasted statistics of these services specially related to subscriber and revenue figures, product features and marketing activities. There are limited indexed researches carried out related to customer satisfaction with reference to Sri Lankan market and service sectors. Some of the researches conducted by private organizations carry business biasness evaluating certain products are superior merely due to business requirements.

\section{Objectives and hypotheses}

Objective 01: Identify the significance and key attributes of customer satisfaction Objective 02: Identify influencing factors for customer satisfaction in generic service context

Objective 03: Derive the key influencing factors which drive and establish customer satisfaction w.r.t. mobile money services 
Objective 04: To make recommendations on mCash business and marketing strategy in order to increase the customer retention level.

\subsection{Development of Conceptual Framework}

Dependent Variable: The dependent variable is establish as the customer satisfaction of mobile-money service as defined in the research problem and discussed under the Materials and Methods. Independent Variables: As per the literature survey on influencing factors for customer satisfaction in general and followed focused study specific to mobilemoney service environment; quality of customer care service, enhanced service convenience, improved security and economical price perception are identified as independent variables.

\section{(Refer Figure 2 Here)}

Fig. 2 shows the logical relationship

between the independent variables and the dependent variable.

In evaluating the relationship highlighted in the conceptual framework, below hypothesis were established for further evaluation.

(Refer Table 1 Here)

\section{Research Methodology}

\subsection{Population Selection and Sample} Size Determination

The population was selected as per the highest revenue generation capability due to the importance in identification of factors influencing for customer satisfaction of this subscriber segment rather than dissolving the findings among total population. Hence identified population consisted of existing mCash users who use a smart phone under a post-paid package. Further, population was clustered as per the distribution of age category.

Sample size was determined based on the mathematical formula detailed in (1);

Sample size $=\frac{Z_{\frac{1-\alpha}{2}}^{2} * p *(1-p)}{d^{2}}$

\section{(1)}

$Z_{\frac{1-\alpha}{2}}=$ standard nominal variant

$\mathrm{P}=$ percentage picking a choice (expected)

$\mathrm{d}=$ confidence interval

Further, sample size was corrected for a finite population. 


\subsection{Data Collection}

A research can be either quantitative or qualitative or mix of both these techniques. A quantities research is considered as an objective techniques conducted by assessing the validity of hypothesis via generated numerical data set. Qualitative research is evaluated subjectively through interviews and other interpretative techniques Wells et al. [41].

This research is carried out based on a quantitative (objective) method since the scope of this research is defined to evaluate the key influencing factors for the customer satisfaction of mCash service and since, the research is not intended to determine additional factors which may have an impact on customer satisfaction. A quantitative method would be resulted in the establishment of the relationship between known variables in a more logical and statistical manner.

The research questionnaire was developed based on a Likert scale where all the responses could be evaluated quantitatively. Further, IBM SPSS version 17 software package was used to statistically analyse the sample data.

\subsection{Data Analysis}

There are several different statistical methods which could be deployed in testing the above parametric of the questionnaire whereas Split-halves testing, KuderRicherdson testing, Guttaman reliability testing, Inter-item correlation testing and Cronbach's alpha testing are widely identified as recommended methods [4]. Cronbach's alpha test is more suitable for multi-level scales since this approach allow not only individual split halves average of all possible combinations but also multilevel average as well and further provides a simple interface rather than singularly testing every possible permutation [36], [18] . Bland \& Altman [3] mention that if a data analysis consists of subscale within primary evaluation parametric, it is better to derive the reliability and consistency of each of the subscales whilst incorporating the primary scales as well. Hence, all the sub scales are also incorporated in the reliability testing. Hence, Cronbach's alpha testing is considered in this research due to the fact that Cronbach's alpha testing provides a more accurate estimate when the responses are expected in a scale such as a Likert scale. 
The Cronbach's alpha was evaluated based on the formula in (2);

Cronbach's alpha $(\alpha)=\frac{N * \bar{c}}{\bar{v}+(N-1) * \bar{C}}$

Where;

$\mathrm{N}=$ Number of individual component, $\hat{\mathrm{c}}=$ average inter term covariance, $\breve{\mathrm{u}}=$ average variance

Several researchers have recommended Alpha values and respective acceptable ranges. George \& Mallery [12] mention that alpha values greater than 0.7 can be considered as the acceptable range if the data analysis is based on a new correlation testing. Alpha value may vary between 0 to 1 whilst the extreme boarders might not be achieved in practical context, however an analysis scale can be considered as acceptable when the alpha value is greater than 0.6. The overall consistency is also evaluated based on the findings of Ferketich et al. [11] whereas item total correlations were tested for the occurrence in the range of 0.3 to 0.7 considering the fact of mobile-money being a relatively new service.

The hypothesis testing was carried out based on two prime factors; scatter diagrams [12] and Pearson coefficients. The
Pearson coefficient ( $\mathrm{Pr}$ ) provides an indication of the correlation of two variables. The correlation can be determined as follows based on the Pearson coefficients [17].The Pearson coefficients are determined as per the formula in (3)

Pearson Coefficient $(\operatorname{Pr})=$ $\frac{\sum x \cdot y-\left(\sum x \cdot \sum y\right) / n}{\sqrt{\left(\sum x^{2}-\left(\frac{\left.\sum x\right)^{2}}{n}\right) \cdot\left(\sum y^{2}-\left(\frac{\left.\sum y\right)^{2}}{n}\right)\right.\right.}}$

Where $\mathrm{x}=$ independent variable, $\mathrm{y}=$ dependent variable, $n=$ number of samples.

\section{Findings and Recommendations}

The Cronbach's alpha was evaluated for all the independent and dependent variable and followed an iterative factor elimination process based on the projected Cronbach's alpha value if the subjected component is eliminated.

\subsection{Quality of Customer Care and Customer Satisfaction}

The Pearson coefficients for the quality of customer care and customer satisfaction provide a value of 0.437 for an $\mathrm{N}$ value of 113 exhibiting a weak positive (almost strong positive) correlation. Further, scatter 
diagram also displays a slight positive correlation with a $\mathrm{R}^{2}$ of 0.191 . Hence, it can be deduced that even though customer care service has an impact on the customer satisfaction of mCash service, it may not be the most critical factor influencing on customer satisfaction.

Since, the Pearson coefficient displays a weak positive correlation, the quality of customer care can be considered as a hygiene factor for customer satisfaction where absence of quality customer care would adversely impact on customer satisfaction whilst existence would not largely contribute for enhanced customer satisfaction.

H1a : High standard in service quality (customer care) has a positive impact on DV (Customer satisfaction of mobilemoney service)

\subsection{Enhanced Service Convenience and Customer Satisfaction}

The Pearson coefficients for high service convenience and customer satisfaction provide a value of 0.197 for an $\mathrm{N}$ value of 113. The value, 0.197 is not significant even at 0.001 . This situation is further revealed in the scatter diagram which has a R2 of 0.039 , and the positive correlation is insignificant.
Hence, the null hypothesis has to be acknowledged regarding high service convenience.

H20: Enhanced service convenience has a null impact on DV (Customer satisfaction of mCash service)

\subsection{Improved Security and Customer Satisfaction}

The Pearson coefficients for improved security and customer satisfaction provides a value of 0.690 , this is a strong positive correlation. This condition is further revealed in the scatter diagram where the two factors are positively correlated with a $\mathrm{R} 2$ value of 0.476 . This is a significant observation and we can conclude that the alternative hypothesis is strongly true.

H3a: Improved security has a positive impact on DV (Customer satisfaction of mCash service) is true

\subsection{Economical Price Perception and Customer Satisfaction}

The Pearson coefficients for economical price perception and customer satisfaction provides a value of 0.845 , this is a strong correlation. This condition is further revealed in the scatter diagram where the two factors are positively correlated with a 
$\mathrm{R} 2$ value of 0.714 . This is a significant observation and we can conclude that the alternative hypothesis is strongly true. In fact, price perception can be considered as the highest correlating factor for customer satisfaction.

H4a: Economical price perception has a positive impact on Dy (Customer satisfaction of mCash service) is true

\section{Conclusion}

This empirical study on key influencing factors for customer satisfaction on mobilemoney services reveal that economical price perception is the most influencing factor for customer satisfaction followed by improved security and quality of customer care.

Above conclusion reinstates the research findings of Ali, et al. [1] where they mention the importance of providing an economical price perception which is justifiable to operating market segment and security and elimination of risk factors are key evaluation factors in choosing modern financial services. Hence, it can be concluded that if mobile operators are to gain significant market share in financial markets, they have to compete with the product features and price of the mobile- money service against other monetary transaction services offered by banks and other financial organizations. Since, mobile operators have the end to end visibility of the service through their centralized monitoring systems; they are in an advantageous position to provide improved security features.

Further, quality of customer care and service convenience may not hugely contribute for the customer satisfaction even though absence of these features may adversely impact on customer satisfaction. Hence, findings of Hasebur [16] are not directly accepted by this study, even though higher service quality has a weak positive correlation to the customer satisfaction, it is not identified as the primary factor. Further, the findings by Kaura [21] and Tojib \& Tsarenko [39] on the impact of service convinience w.r.t. to emerging services for retail markets are not justified by this research. This may be due to the difference in cultural background and the value propostion of a developing market compared with that of a developed market which shall be emperically establish in a future comparative research study. 


\section{References}

[1] Ali, S., Bahram, R., Ali, S. \& Azarnoosh, A., 2011. Determinants of Customer Loyalty Using Mobile

Payment Services in Iran.

Interdisciplinary Journal of

Contemporary Research In Business, III(6), pp. 22-34.

[2] Black, J., Hashimzade, N. \& Myles, G., 2012. A Dictionary of Economics. 4th ed. Oxford, United Kingdom: Oxford University Press.

[3] Bland, J. \& Altman, D., 1997. Statistics notes: Cronbach's alpha, s.l.: BMJ

[4] Bonett, D. \& Wright, T., 2014. Cronbach's alpha reliability: Interval estimation, hypothesis testing, and sample size planning. Journal of Organizational Behavior, XXXVI(1), pp. $3-15$.

[5] Bradley, L., \& Stewart, K. 2003. A Delphi study of Internet banking. Marketing Intelligence \& Planning, 21 (5), 272-281

[6] Casaló, L., Flavián, C., \& Guinalíu, M. 2007. The role of security, privacy, usability and reputation in the development of online banking. Online

Information Review, 31(5), 583-603.

[7] Castri, S. 2013. Enabling Mobile Money Policies in Sri Lanka - The Rise of eZ Cash. Mobile Money for the Unbanked.

\section{S.1. GSMA}

[8] Chang, Y., Polonsky, M. \& Junek, O., 2008. A Preliminary Examination of Berry, Seiders and Grewal's (2002) Five Dimensional Measure of Convenience, Melbourne: Victoria University.

[9] Churchill, G. (., 1979. A paradigm for Developing Measures of Marketing Constructs. Journal of Marketing Research, XVI(1), pp. 64-73.

[10] Elkhani, N. \& Bakri, A., 2010. Review on "Expectancy Disconfirmation Theory" (EDT). Journal of Information Systems and Innovation, Volume III, pp. 65-78.

[11] Ferketich, A., Wee, A., Shultz, J. \& Wewers, C., 2007. A Measure of Nicotine Dependence for Smokeless Tobacco Users. Addictive Behaviors, XXXII(9), p. 1970-1975.

[12] George, D., \& Mallery, P. 2003. SPSS for Windows step by step: A 
simple guide and reference. 11.0 update (4th ed.). Boston: Allyn \& Bacon.

[13] GSMA, 2014. Mobile Money in the Philippines - The Market, the Models and Regulation, s.l.: GSMA.

[14] Ha, H., John, J., Janda, S. \& Muthaly, S., 2011. Europian Journal of MArketing. Europian Journal of Marketing, XLV(4), pp. 673-684.

[15] Han, H. \& Ryu, K., 2009. The Roles of the Physical Environment, Price Perception, and Customer Satisfaction in Determining Customer Loyalty in the Restaurant Industry. Journal of Hospitality \& Tourism Research, XXXIII(4), pp. 487-510.

[16] Hasebur, R., 2014. Factors Affecting Customer Satisfaction in Mobile Telecommunication Industry in Bangladesh. Business, Management \& Education / Verslas, Vadyba ir Studijos., XII(1), pp. 74-93.

[17] Janosky, J. E., 1991. Pearson Correlation Coefficients vs Reliability Coefficients. Journal of the American Dietetic Association, XCI(8), pp. 912-3.
[18] Jiang, J., Klein, G. \& Saunders, C., 2012. Customer Satisfaction Conceptual Issues Consumer Satisfaction Theories A Critical Review, s.l.: Business UQ.

[19] Jiang, P., 2008. Managing Customer Price Perceptions: An Empirical Investigation on the Impacts of ETailing Services. Services Marketing Quarterly, 22 09, pp. 77-98.

[20] Kariyakarawana, K., 2014. Nuisance calls and nasty messages: Could be life threatening, Colombo: Lake House.

[21] Kaura, V., 2013. Service Convenience, Customer Satisfaction, and Customer Loyalty: Study of Indian Commercial Banks. Journal of Global Marketing, XXVI(1), pp. 18-27.

[22] Kotler, P., 2000. Marketing Management. 10th ed. New Jersy: Prentice Hall.

[23] Kyriazopoulos, P. \& Rounti, I., 2008. Problems and Opportunities of the Relationship between the First and Second Generation of Self Managing Family Business, Athens: Graduate Technical Education Institute of Piraeus. 
[24] Lin, C. \& Wei, Y., 2013.

Measurement of Discomformation in Online Purchasing Behavior. s.l., TIIM.

[25] Noorshella, N., Che, B., Abdullah, A. \& Nursalihah Ahmad, R., 2015. Examining Customer Satisfaction at the Point-of-Purchase Phase: A Study on Malaysian e-Consumers. Asian Social Science, XI(16), pp. 88-97.

[26] O'Brien, L. \& Jones, C., 1995. Do Rewards Really Create Loyalty. Harvard Business Review, May-June, pp. 75-82.

[27] Oliver, R., 1977. Theoretical Representation of Expectation and Disconfirmation Effects on PostExposure Product Evaluations: Experience in the Field. s.l., Indiana University.

[28] Oliver, R., 1993. Cognitive, Afective and Atribute Bases of the Satisfaction Response. Journal of Consumer Research, Issue 14, pp. 495-507.

[29] Parasuraman, A., Zeithaml, V. \& Berry, L., 1985 . A Conceptual Model of Service Quality and Its Implications for Future Research. Journal of Marketing, Volume XLIX, pp. 41-50.
[30] Pénicaud, C. \& Katakam, A., 2013. State of the Industry - Mobile Financial Services for the Unbanked, s.l.: GSMA.

[31] Piazo-Vela, S., 2009. The Effect of Online Reviews on Customer Satisfaction: Expectancy

Disconfirmation Approach. s.l., AMICS.

[32] Safaricom Limited, 2014. News Release - Annual Report, Nirobi, Kenya: Safaricom Limited.

[33] Shanker, V. \& Carpenter, G., 2012. Handbook of Marketing Strategy, s.l.: Edward Elgar Publishing.

[34] Spreng, R. A., MacKenzie, S. B., \& Olshavsky, R. W. (1996). A reexamination of the determinants of consumer satisfaction. Journal of Marketing 60, 15-32

[35] Sri Lanka Telecom Group, 2014. SLT Annual Report. [Online] Available at: http://www.slt.lk/en/content/2014annual-report [Accessed 12 December 2015].

[36] Streiner, D. \& Kottner, J., 2010. Internal consistency and Cronbach's $\alpha$ : A comment on Beeckman et al. (2010). 
International Journal of Nursing

Studies, XLVII(7), p. 926-928.

[37] Suri, R., Manchanda, V.R., Kohli, S.C (2002). Comparing fixed price and discounted price strategies: the role of affect on evaluations. Journal of Product \& Brand Management, 11(3), pp.160171.

[38] Thalgodapitiya, R., 2015. Sri Lankan Banking Sector, Colombo: Fitch Ratings.

[39] Tojib, D. \& Tsarenko, y., 2012. Postadoption modeling of advanced mobile service use. Journal of Business Research, LXV(7), pp. 922-928.

[40] Tse, D. \& Wilton, P., 1988. Models of Customer Satisfaction Formation: An Extention. Journal of Marketing Research, Volume XXV, pp. 204-212.

[41] Wells, R. S., Williams, E. A., Kolek, E. A. \& Saunders, D. B., 2015. How we know what we know": A systematic comparison of research methods employed in higher education journals,
1996-2000 v. 2006-2010. Journal of Higher Education, LXXXVI(2), pp. 171198 .

[42] Westbrook, R. \& Reilly, M., 1983. Value-Percept Disparity: an Alternative to the Disconfirmation of Expectations Theory of Consumer Satisfaction. Advances in Consumer Research, Volume X, pp. 256-261.

[43] Wirtz, J., 1993. A critical Review of Models in Consumer Satisfaction. Asian Journal of Marketing, Volume II, pp. 722.

[44] Yukse, A. \& Yüksel, F., 2015. Customer Satisfaction: Conceptual Issues Consumer Satisfaction Theories: A Critical Review. [Online] Available at: http://www.researchgate.net/publication/ 258180675_Customer_Satisfaction_Con ceptual_Issues_Consumer_Satisfaction_ Theories_A_Critical_Review [Accessed 04 July 2015]. 


\section{List of Figures:}

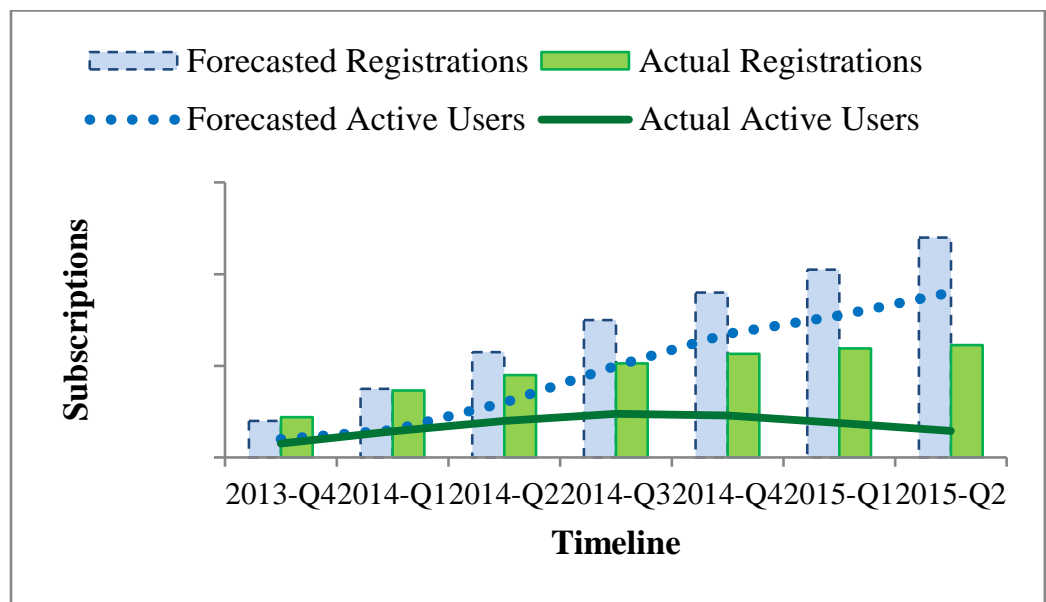

Figure 1: forecasted and active subscribers of mCash service

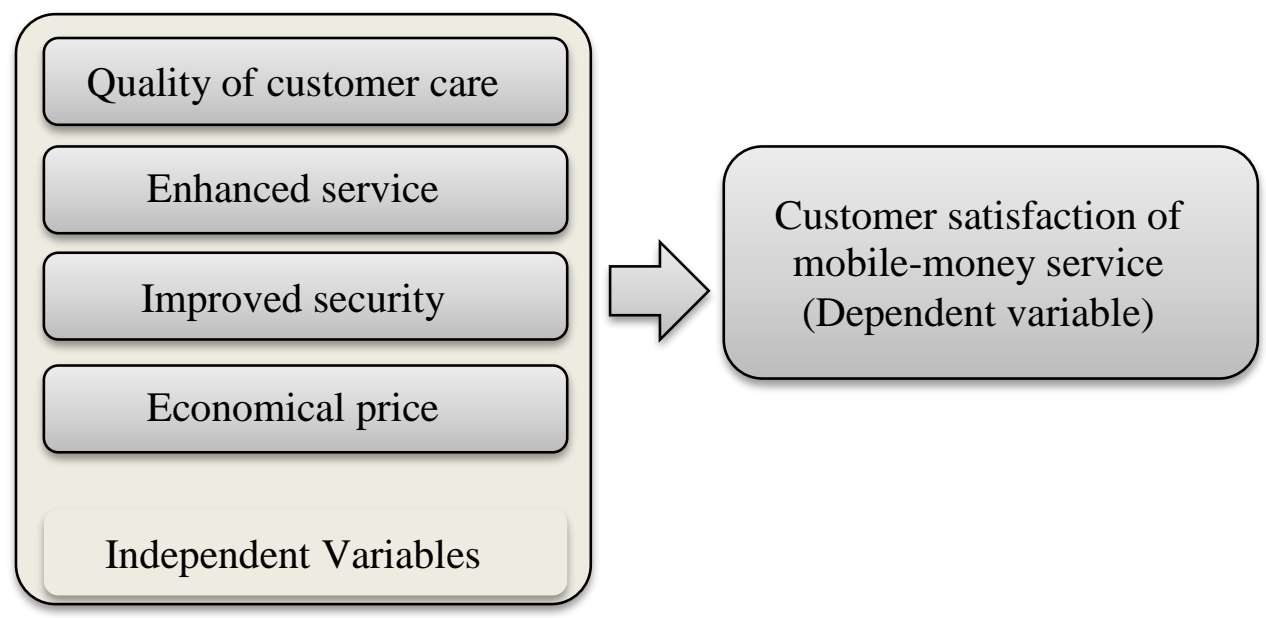

Figure 2: Conceptual Framework 
List of Tables

Table 1: development of hypothesis

\begin{tabular}{|l|l|l|l|}
\hline \multicolumn{2}{|c|}{ Alternative Hypothesis (HNa) } & \multicolumn{2}{c|}{ Null Hypothesis (HNo) } \\
\hline $\mathrm{H} 1_{\mathrm{a}}$ & $\begin{array}{l}\text { High standard in service quality } \\
\text { (customer care) has a positive impact } \\
\text { on Dependent Variable (DV) }\end{array}$ & $\mathrm{H} 1_{0}$ & $\begin{array}{l}\text { High standard in service quality } \\
\text { (customer care) has null impact on } \\
\text { DV }\end{array}$ \\
\hline $\mathrm{H} 2_{\mathrm{a}}$ & $\begin{array}{l}\text { Enhanced service convenience has a } \\
\text { positive impact on DV }\end{array}$ & $\mathrm{H} 2_{0}$ & $\begin{array}{l}\text { Enhanced service convenience has a } \\
\text { null impact on DV }\end{array}$ \\
\hline $\mathrm{H} 3_{\mathrm{a}}$ & $\begin{array}{l}\text { Improved security has a positive } \\
\text { impact on DV }\end{array}$ & $\mathrm{H} 3_{0}$ & $\begin{array}{l}\text { Improved security has null impact on } \\
\text { DV }\end{array}$ \\
\hline $\mathrm{H} 4_{\mathrm{a}}$ & $\begin{array}{l}\text { Economical price perception has a } \\
\text { positive impact on DV }\end{array}$ & $\mathrm{H} 4_{0}$ & $\begin{array}{l}\text { Economical price perception has null } \\
\text { impact on DV }\end{array}$ \\
\hline
\end{tabular}

Table 2: final Cronbach's alpha values

\begin{tabular}{|l|l|r|r|}
\hline & Contributing item & $\begin{array}{c}\text { Cronbach's } \\
\text { Alpha }\end{array}$ & N of Items \\
\hline \multirow{4}{*}{ Independent Variables (IV) } & Customer care & 0.739 & 5 \\
\cline { 2 - 4 } & Service convenience & 0.432 & 4 \\
\cline { 2 - 4 } & Security & 0.426 & 4 \\
\cline { 2 - 4 } & Price perception & 0.522 & 4 \\
\hline Dependent variable (DV) & Customer satisfaction & 0.656 & 5 \\
\hline
\end{tabular}

In evaluating the validity of hypothesis, each of the independent variable was evaluated against the dependent variable as per scatter diagrams and Pearson coefficients. 
ISSN 2349-2317 (Online); DOI: 10.16962/EAPJMRM/issn. 2349-2317/2015; Volume 7 Issue 2 (2016)

Table 3: Pearson Coefficient (Pr), Regression Coefficient $\left(\mathrm{R}^{2}\right)$ and significance

\begin{tabular}{|l|l|l|l|}
\hline Parameter & $\begin{array}{l}\text { Pearson coefficient } \\
(\mathrm{Pr})\end{array}$ & $\begin{array}{l}\text { Regression } \\
\text { coefficient }\left(\mathrm{R}^{2}\right)\end{array}$ & Significance \\
\hline $\begin{array}{l}\text { Mean customer satisfaction (Y) } \\
\text { vs Mean customer care level }\end{array}$ & 0.437 & 0.191 & $\begin{array}{l}\text { Weak positive } \\
\text { correlation }\end{array}$ \\
\hline $\begin{array}{l}\text { Mean customer satisfaction (Y) } \\
\text { vs Mean service convenience } \\
\text { level }\end{array}$ & 0.197 & 0.039 & $\begin{array}{l}\text { Weak positive } \\
\text { correlation }\end{array}$ \\
\hline $\begin{array}{l}\text { Mean customer satisfaction (Y) } \\
\text { vs Mean security level }\end{array}$ & 0.69 & 0.476 & $\begin{array}{l}\text { Strong positive } \\
\text { correlation }\end{array}$ \\
\hline $\begin{array}{l}\text { Mean customer satisfaction (Y) } \\
\text { vs Mean price perception level }\end{array}$ & 0.845 & 0.714 & $\begin{array}{l}\text { Strong positive } \\
\text { correlation }\end{array}$ \\
\hline
\end{tabular}

